\title{
The Profile Quality of Pond In Kendal Regency to Diversification Aquaculture
}

\author{
Ligar Novi Ayuniar $^{1}$ and Jafron Wasiq Hidayat ${ }^{2}$ \\ ${ }^{1}$ Master Program of Environmental Science, School of Postgraduate Studies, Diponegoro University \\ ${ }^{2}$ Biology Dept, Faculty of Science and Mathematic, Diponegoro University
}

\begin{abstract}
Water quality, particularly coastal areas, is systematically tropogenic. The decline in water quality is caused by industrial waste pollution, soil erosion carried by the river, and the depletion of mangrove areas. The decrease of water quality can affect the fishery cultivation activities that exist in the region. It also affects the quality of the cultivated fish. Fish cultivated in ponds with poor water quality can be harmful to the health of the people who consume the fish. One effort to manage the feasibility of pond waters is by identifying the quality. The purpose of this research is to know the profile of pond water quality and to know the diversity potential of aquaculture. Based on the nature of the problem this research is a field research, while the purpose of this study is descriptive and explanatory research. The method used in this research is research by using survey method. Aquatic profile results are essential to improve the quality and quantity of Fisheries, especially in diversifying fisheries.
\end{abstract}

\section{Introduction}

Pond is one type of habitat that is used as a place for brackish water cultivation activities located in coastal areas. Continuous aquaculture activities lead to environmental degradation, which is characterized by a decrease in water quality. Environmental constraints encountered in the cultivation activities include the arrangement of the area or the arrangement of cultivation development space that does not pay attention to the carrying capacity of the environment due to improper management, resulting in environmental problems with all aspects of complications in a long period [1]. Good water quality in fish ponds benefited fish for prospering plankton as foods, buffering harmful matters, etc., and poor water quality easily resulted in lessening fish yields and cheapening production quality. How to balance water qualities was a technical skill in pond farming, and monitoring parameters of water quality might be the first step. On the other hand, aquaculture pond effluents can potentially harm the environment, although in some cases, the effluents have been environmentally negligible. Governments and organizations have developed limitation guidelines and standards for aquaculture effluents. A few variables have been used to evaluate aquaculture water qualities, for example, total suspended solids (TSS), turbidity (Tur), total particulate organic matter (POM), total nitrogen (TN), total phosphorus (TP), 5 day biochemical oxygen demand (BOD), and total settleable solids (Set). Aquaculture producers ought to measure variables to know the status of fish pond waters and comply with the standards for aquaculture effluents, and the more variables that were measured, the higher the cost [2].

Kendal Regency consists of 20 districts, has a fairly complete area, consisting of beaches, lowlands, highlands and mountains. With a coastline of approximately $42.2 \mathrm{~km}$, it has enough potential resources to be cultivated and developed, both for freshwater / pond, brackish water and marine aquaculture. Based on data from the Livestock, Marine and Fisheries Service Office (DPKP) of Kendal Regency, for brackish water aquaculture (tambak) is located in 7 sub districts of Kendal namely Kaliwungu, Brangsong, Kendal, patebon, Cepiring, Kangkung and Rowosari. Area of ponds in the region of Kendal reached 3,292.22 ha, with the number of fish cultivators as many as 1,084 people. Leading commodities consist mostly of milkfish, shrimp vename, and tiger shrimp [3]. Seeing the state of Kendal Regency considerable potential for the development of aquaculture, it is possible this has a negative impact on the environment, for example, the declining quality of the water. So there needs to be further research on pond water quality and diversification of aquaculture in ponds of Kendal Regency.

\section{Study Literature}

Water quality is the nature of water and the content of living organisms, substances, energies, or other components in the water expressed by several parameters such as physical parameters (temperature,

Corresponding author: ligar.novi@gmail.com 
turbidity, suspended solids, etc.), chemical parameters ( $\mathrm{pH}, \mathrm{DO}, \mathrm{BOD}$, and Etc.), and biological parameters (plankton, bacteria, and Etc.)[4]. Water quality has a very important role for cultivation life. For example, water temperatures can affect many processes in both biology, physics and water chemistry. The increase in temperature that can still be tolerated by the organism will be followed by an increase in the degree of metabolism and the activity of photosynthesis of natural food (phytoplankton). Similarly, water temperature will affect survival, morphological growth, reproduction, behavior, rate of skin turnover (for shrimp) and shrimp metabolism. The magnitude of the influence of water temperature on life is determined by the tolerance and the speed of changes in water temperature. The degree of acidity $(\mathrm{pH})$ of water shows the levels of hydrogen ions or protons contained in water. $\mathrm{pH}$ affects the process and speed of chemical reactions in water media as well as biochemical reactions in the shrimp body, affecting the toxicity of a compound, the survival and growth of shrimp. Each type of organism has a different tolerance to changes in $\mathrm{pH}$ [5].

Brightness is a measure of water transparency, which is determined visually by using a secchi disk. Brightness is measured directly in the field in a way until it can be distinguished between black and white on the secchi disk [6]. Water depth is also measured using secchi disk, by reversing the secchi disk with black and white disk position above it after measuring the depth of the pond by inserting the disk secchi and record the result.

The amount of dissolved oxygen in the water is very important for aquatic organisms. This is because dissolved oxygen affects the growth, survival, distribution, behavior, and physiology of shrimp and other aquatic organisms. The oxygen distribution also strongly influences the solubility of organic nutrients. The presence of oxygen is also used to determine whether the environment is in aerobic or anaerobic conditions [7]. Salinity can affect the oxygen content in the water, the higher the salinity level the dissolved oxygen will also be lower. Plankton also has an optimum growth range at high salinity. Nitrites are also affected by dissolved oxygen levels so that nitrite is an unstable gas. In naturally occurring waters nitrite is typically found in small amounts and displaces the transitional forms between ammonia and nitrate (nitrification), and between nitrate and nitrogen (denitrification). The source of nitrate can be industrial waste or domestic waste [8]. Ammonia is a substance that causes a very sharp smell and piercing the nose. Ammonia content (NH3) is a parameter of water quality that must be considered, because the ammonia found in waters when the levels exceed the limit will be able to harm the aquatic organisms [6].

Uncontrolled water quality can have a negative impact on the environment around the pond, one example is the occurrence of eutrophication. Of all the pollution sources, aquaculture is one of the main reasons for the high level of nutrients. Aquaculture accelerates eutrophication in lakes and reservoirs due to its adverse effects on water quality and the ecosystem [9]. The discharge of aquaculture pond effluents could be an important contributor to the problem of water pollution and eutrophication in the receiving waters of the coastal zones in China. Effective treatment of aquaculture pond effluents before discharge will become an important challenge in the future in alleviating the pressures of eutrophication in the coastal zone [10].

Water conditions must be strictly controlled to maintain water quality conditions in order to be able to support the life and health of aquaculture organisms [11], but there is also a need to limit the number of ponds so as not to have a negative impact on the environment. Whereas in Indonesia, most of the fishery cultivation waste is feed that is not consumed by fish around the pond. Clearly there is a need to limit the number of ponds in a particular area so that the ecological carrying capacity of the water body in which the pond is installed is not exceeded, with undesirable biota and water quality changes [12]. In addition to these two things, the need for consideration for the location of ponds that will be used. For example for brackish water ponds. This as most brackish water ponds are set in river deltas where fresh water historically has been lost to the ocean anyways. Redirecting the flow of water into shrimp ponds could, however, affect natural estuarine ecosystems as these have been shaped by natural fluctuations in salinity. Future research should therefore identify at which scales redirecting river flows into brackish water ponds start to have negative impacts on local ecosystems, and whether zoning and area based management could reduce these negative effects[13].

\section{Water Quality Parameters}

The range of these parameters is based on the Decree of the Minister of Marine Affairs and Fisheries Number: Kep. 28 / Men / 2004 About the General Guidelines for Shrimp Farming in Ponds [14].

Table 1. Sources Water Quality Parameters

\begin{tabular}{|l|l|}
\hline Parameter & Range \\
\hline Salinity (ppt) & $5-35$ \\
pH & $7,0-9,0$ \\
Alkalinity (ppm) & $>50$ \\
$\mathrm{H}_{2} \mathrm{~S}(\mathrm{mg} / \mathrm{l})$ & 0,001 \\
Organic matter (ppm) & $<55$ \\
Total phosphate (ppm) & $0,05-0,50$ \\
BOD (ppm) & $<25$ \\
COD (ppm) & $<40$ \\
TSS (ppm) & $25-500$ \\
\hline
\end{tabular}


Information:

$\mathrm{BOD}=$ Biochemycal Oxygen Demand

$\mathrm{COD}=$ Chemycal Oxygen demand

TSS $=$ Total Suspended Solid

Table 2. Shrimp Pond Quality Effluent Standards

\begin{tabular}{|l|l|l|}
\hline Parameter & Unit & Value \\
\hline TSS & $\mathrm{mg} / \mathrm{l}$ & $\leq 200$ \\
$\mathrm{pH}$ & & $6-9$ \\
$\mathrm{BOD}$ & $\mathrm{mg} / \mathrm{l}$ & $<45$ \\
$\mathrm{H} 2 \mathrm{~S}$ & $\mathrm{mg} / \mathrm{l}$ & $<0,03$ \\
$\mathrm{NO} 3$ & $\mathrm{mg} / \mathrm{l}$ & $<75$ \\
$\mathrm{NO} 2$ & $\mathrm{mg} / \mathrm{l}$ & $<2,5$ \\
$\mathrm{NH} 3$ & $\mathrm{mg} / \mathrm{l}$ & $<0,1$ \\
\hline
\end{tabular}

Based on Government Regulation No. 20 of 1990 that water used for fishery and livestock activities is found in class $\mathrm{C}$ [15].

Table 3. Water quality data that can be used for fisheries

\begin{tabular}{|c|c|c|c|}
\hline Parameter & Unit & $\begin{array}{c}\text { Maximum } \\
\text { levels [15] }\end{array}$ & $\begin{array}{c}\text { Optimum } \\
\text { range [16] }\end{array}$ \\
\hline $\mathrm{NH}_{3}$ & $\mathrm{Mg} / 1$ & 0,02 & \\
\hline $\mathrm{NO}_{2}$ & $\mathrm{Mg} / 1$ & 0,06 & \\
\hline $\mathrm{DO}$ & $\mathrm{Mg} / 1$ & $\begin{array}{c}\text { Required } \\
\geq 3\end{array}$ & $>5$ \\
\hline $\mathrm{pH}$ & - & $6-9$ & $6,5-9$ \\
\hline temperature & ${ }^{\circ} \mathrm{C}$ & & $28-32$ \\
\hline brightness & $\mathrm{cm}$ & & $30-40$ \\
\hline Salinity & $\mathrm{ppm}$ & & $5-25$ \\
\hline
\end{tabular}

In this study, the presence of plankton also play a role in the life of aquaculture cultivation. Plankton calculation is done by collecting plankton using plankton net. Since plankton is the basis of the food web, there is a close relationship between plankton abundance and fish production [17].

Once we know the quality standards of water quality for aquaculture, then we can know the potential of diversification of any fishery business that can be done in the area. Suppose the cultivation of shrimp-milkfish, milkfish-seaweed, or seaweedshrimp. The purpose of this diversification is to minimize the risk of failure of fishery cultivation business, is expected to increase the income of coastal communities, especially fish farmers, take advantage of spare time or take advantage of assets owned, and preserve nature.

\section{Method}

This method refers to scientific research conducted by Anggoro Prihutomo [18]:

\section{Materials and Research Tools}

Materials used in this study include area maps or maps of pond farm use, GPS, sample bottles, label paper, secchi disk, $\mathrm{pH}$ meter, DO meter, refractometer, thermometer, plankton net, stationery, observation sheet, questionnaire, and camera.

\section{Types and Research Methods}

Based on the nature of the problem this research is a field research, while the purpose of this study is descriptive and explanatory research [19]. Judging from the analytical approach, this research is a kind of research with qualitative and quantitative approach, whereas from the depth of the analysis this research is a kind of inferential research which relies the conclusion of research result on a probability of rejection of null hypothesis. The method used in this research is research by using survey method, that is method that does not make changes (no special treatment) to the variables studied [20].

\section{Assessed Parameters}

1. Physical parameters include: temperature, brightness, suspended particle charge, and salinity. 2. Chemical parameters include: dissolved oxygen (DO), $\mathrm{pH}, \mathrm{BOD}, \mathrm{NO}_{2}$.

3. Biological parameters include: Phytoplankton and Zooplankton.

\section{Research Assessment}

The scope of the study includes the description of the existing condition of the area and the environmental quality study. Description includes the general condition of the area, the activities developed and the environmental management undertaken. The study of pond quality quality is water quality description in a water quality index value in ponds with various aquaculture system.

\section{Sample Research}

The sample in this research is pond water from various aquaculture system. Selection of pond plot taken as sample is done non-random or non probability sampling with purposive sampling method. The pond samples were determined based on criteria based on the extensive representation of ponds and ponds with semi-intensive or intensive systems, the representation of the location of pond blocks, and the cultivation lifespan.

\section{Data collection technique}

Primary data obtained from observation and interview. Observations were conducted in both insitu and exsitu through laboratory analysis and interviews with actors of aquaculture activities in the 
study sites. Fill interviews through the aquaculture system undertaken, technical production processes from input to output. Secondary data is obtained from the literature study, activity report, previous production data archive related to this research. Secondary data is needed to support the completeness of primary data to obtain more complete information.

\section{Determination of Pond Sample}

Determination of ponds to be sampled is done through the results of initial observation visually to map the aquaculture system used as well as aquaculture commodities that are cultivated. In the aquaculture / pond technicians interviewed the maintenance system and maintenance age. After that the ponds with the technical condition of maintenance and maintenance age are almost the same calculated to be samples. Total ponds that develop intensive and traditional brackish water commodities are the study population, and from that population it is determined $10 \%$ to be the research sample. The distribution of pond samples is attempted to represent every area block in the research area and the aquaculture system.

\section{Pond Water Sampling Technique}

Water sampling is done on the mornings once a week for one month. Special parameters DO and temperature are measured in the morning and afternoon in situ, assuming the highest oxygen solubility (afternoon) and lowest (morning). Samples of water analyzed exituately in the laboratory were taken using bottles of $600 \mathrm{ml}$. Sampling is done at the midpoint of the water pool. Water quality parameters to be observed include physical parameters, chemical parameters, and biological parameters. Physical parameters include temperature, brightness, water depth, light intensity, and turbidity. Water chemistry parameters include $\mathrm{DO}, \mathrm{pH}, \mathrm{BOD}, \mathrm{NO}_{3}$, and $\mathrm{PO}_{4}$. Biological parameters include density and plankton diversity.

\section{Sample Analysis}

The temperature parameters determined in situ using a mercury thermometer, dissolved oxygen were analyzed in situ using a DO meter, $\mathrm{pH}$ was measured using $\mathrm{pH}$ meters, brightness and depth by insitu using a secchi disk, and salinity using a refractometer. Total ammonia was tested using indofenol reaction, while nitrite with sulfanilamide staining method [21]. Plankton samples were taken by filtering $20 \mathrm{~L}$ of water using a net plankton with a hole diameter of 25 $\mu \mathrm{m}$. Plankton observations include the abundance and diversity index $\left(\mathrm{H}^{\prime}\right)$ of plankton present in pond water.

\section{Plankton abundance}

Calculations of plankton abundance were performed using the Haemocytometer aids seen using a microscope tool. The abundance of plankton species was calculated based on the following equation principle [22]:

$\mathrm{D}=(l / p) \mathrm{q} l / v$

Information:

$\mathrm{D}=$ number of unity volume plankton

$\mathrm{Q}=$ number of plankton in subsample

$\mathrm{P}=$ subsample volume

$\mathrm{L}=$ sample volume

$\mathrm{V}=$ volume of filtered water

Plankton Diversity

Plankton diversity expressed in a ShannonWiener Index is used to calculate the diversity index according to Odum by the following formula:

$H^{\prime}=-\sum_{i=1}^{s}\left(\frac{n i}{N}\right) \ln \left(\frac{n i}{N}\right)$

Information

$\mathrm{H}^{\prime}=$ Shannon-Wiener diversity index

$\mathrm{Ni}=$ the number of individual types of $\mathrm{i}$

$\mathrm{N}=$ total number of individuals throughout the genera

(Where $\mathrm{S}=$ number of types)

\section{Data Analysis Research}

Analysis of the existing condition of the aquaculture area is the data obtained is analyzed descriptively, so it can describe the aquaculture area. Determination of quality status of pond environment is done by analyzing descriptively water quality data of measurement result into a quantitative value in the form of Water Quality Index (WQI).

$$
\mathrm{WQI}=\Sigma(S i x W i)
$$

Information:

$\mathrm{Si}=$ Scores of water quality indicator values $\mathrm{Wi}=$ Weight index of each water quality

The value of $\mathrm{Si}$ and $\mathrm{Wi}$ is standardized from 0 to 1 , and therefore the WQI value is also calculated by the range of values 0 to 1 . The scoring method or weighting of each parameter is adjusted to the importance of the function of each parameter in supporting the life of aquaculture organism.

Weighting is given subjectively. Physical, chemical, and biological properties are given almost 
equal weight, since the three indicators have an equally important function (weight value 1). Each indicator is assigned a factor called sub-weight (weighted value 2) whose weight assessment may differ for each individual depending on the individual's role of the water parameter.

The determination of the effect of the aquaculture system on the environmental status of the pond was done statistically by analyzing the variety (ANOVA) and if there was a significant effect followed by the mean test (compare means) using the Tukey HSD (Honestly Significant Different) test. Analysis of the influence relationship between parameters of water quality was analyzed using multiple linear regression statistic analysis.

\section{Conclusion}

Water quality plays an important role to the success of aquaculture, by knowing the water quality profile in a region then we can identify the potential of diversification of aquaculture what can be done in the pond. As is known, the purpose of this diversification is to minimize the risk of failure of fishery cultivation business, is expected to increase the income of coastal communities, especially fish farmers, take advantage of spare time or take advantage of assets owned, and preserve nature.

\section{Reference}

1. [S. M. Niti. J Saintek Fisheries Vol. 4, No. 1, 50-55(2008).

2. Zhongneng $\mathrm{Xu}$, Claude E. Boyd. Reducing the monitoring parameters of fish pond water quality. Aquaculture. 465, 359-366 (2016).

3. Ristiyani Dwi. Evaluation of Land Suitability for Fish Pond Fisheries in Kendal Coast. Geo Image 1, 12-18 (2012).

4. H. Effendi, Water Quality Study for Resource Management and Water Environment. Yogyakarta: Kanisius. (2003).

5. Suwarsih, Marsoedi, Nuddin Harahab, Mohammad Mahmudi. Proceedings of the National Marine Seminar (2016)

6. Putra Reza Rammiko, Dr. Dedi Hermon, Mp, Farida S.Si, M.Sc. Brackish Water Quality Study For Aquaculture In Coastal Area Linggo Sari Baganti Sub-district South Pesisir Regency.

7. AA. Ekubo, JFN. Abowei, Applied Sciences, Engineering and Technology 3. No 12 (2011) 1342-1357.

8. Makmur, Rachmansyah, and Mat Fahrur. The Relationship Between Water Quality and Plankton in Ponds Tanjung Jabung
Barat Regency Jambi Province. The Center for Brackishwater Aquaculture Research. South Sulawesi.

9. Huai-dong ZHOU, Cui-ling JIANG, Li-qin ZHU, Xin-wei WANG, Xiao-qin HU, Junyu CHENG, Ming-hua XIE. Water Science And Engineering, (2011), 4(1): 92-100.

10. Ping Yang, Derrick Y.F. Lai, Baoshi Jin, David Bastviken, Lishan Tan, Chuan Tong. Science of the Total Environment 603-604 (2017) 256-26.

11. Kilawati Yuni, Yunita Maimunah. Research Journal Of Life Science E April- (2015) Vol 02 No. 01: 50-59.

12. [Edwards Peter. Aquaculture 447 (2015) 214.

13. Henriksson Patrik John Gustav, Nhuong Tran, Chadag Vishnumurthy Mohan, Chin Yee Chan, U-Primo Rodriguez, Sharon Suri A, Lara Dominguez Mateos, Nur Bambang Priyo Utomo, Stephen Hall, Michael John Phillips. Journal Of Cleaner Production 162 (2017) 1482-1490.

14. Decree of the Minister of Marine Affairs and Fisheries Number: Kep. 28 / Men / 2004 About the General Guidelines for Shrimp Farming in Ponds.

15. Government Regulation number 20 of 1990 on Water Container Control.

16. M. Kordi, H. Ghufran, Andi Baso Tancung. (2005). Water Quality Management in Aquaculture. Publisher Rineka Cipta.

17. A. Bhatnagar and P. Devi, International Journal of Environmental Sciences, Vol. 3, No. 6, (2013) 1980-2009.

18. Prihutomo Anggoro. Quality Status of Biological Physics and Chemistry (BIOFISKIM) and Supporting Power of Pond Environment in BLUPPB Karawang Aquaculture Area of West Java. Diponegoro University. (2015).

19. Suryana, (2010) Research Methods Practical Model of Quantitative and Qualitative Research, Bandung: UPI.

20. Dharminto, (2007), Research Methods and Sample Research. http://eprints.undip.ac.id/5613/1/METODE PENELITIAN - dharminto.pdf.

21. S. Nimrat, S. Suksawat, P. Maleeweach \& V. Vuthiphandchai. (2008). Aquaculture. 285: $123-129$

22. W. Wardhana, (2003). Sampling Techniques Preservation and Plankton Analysis. [Journal]. Presented in Sampling Technique Training and Plankton Identification. Fishery Quality Development and Testing Center. Jakarta. 